\title{
Corynebacterium sputi sp. nov., isolated from the sputum of a patient with pneumonia
}

Correspondence

A. F. Yassin

yassin@mibi03.meb.uni-bonn.de

\author{
A. F. Yassin ${ }^{1}$ and C. Siering ${ }^{2}$ \\ ${ }^{1}$ Institut für Medizinische Mikrobiologie und Immunologie der Universität Bonn, Sigmund-Freud- \\ Straße 25, D-53127 Bonn, Germany \\ ${ }^{2}$ Kekulé-Institut für Organische Chemie und Biochemie der Universität Bonn, D-53121 Bonn, \\ Germany
}

\begin{abstract}
A coryneform bacterium isolated from the sputum of a patient with pneumonia was characterized by phenotypic and molecular taxonomic methods. Chemotaxonomic investigations revealed the presence of cell-wall chemotype IV and short chain mycolic acids consistent with the genus Corynebacterium. Comparative 16S rRNA gene sequencing studies confirmed this assignment, with the organism forming a hitherto unknown subline within the genus associated with a subcluster containing Corynebacterium hansenii, Corynebacterium freneyi, Corynebacterium xerosis, Corynebacterium amycolatum and Corynebacterium sphenisci. Sequence divergence values of $>2.7 \%$ from established corynebacterial species suggested that the new isolate represented a novel species. This was also supported by the results of the biochemical tests. On the basis of phenotypic and phylogenetic evidence, it is proposed that the unknown bacterium be classified as a novel species of the genus Corynebacterium, Corynebacterium sputi sp. nov. (type

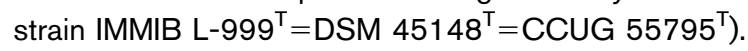

Currently the genus Corynebacterium comprises more than 80 species, a high proportion of which have been described relatively recently as a result of the use of much-improved phenotypic and molecular identification methods. Most of the newly described species of the genus Corynebacterium have been isolated from human (e.g. Funke et al., 1997a, 1998; Renaud et al., 2001, 2007; Yassin et al., 2002a, b) or animal (e.g. Fernández-Garayzábal et al., 1998, 2004; Goyache et al., 2003; Collins et al., 2001, 2004) clinical sources. During the course of the characterization of bacterial isolates encountered from clinical sources, we found a Gram-positive, rod-shaped organism which had chemotaxonomic characteristics consistent with its provisional assignment to the genus Corynebacterium. Further taxonomic and phylogenetic investigations indicated that the novel strain was different from previously described species of the genus Corynebacterium. Based on phylogenetic and phenotypic evidence, it is proposed that this isolate, designated IMMIB L- $999^{\mathrm{T}}$, is a novel species of the genus Corynebacterium.

Strain IMMIB L- $999^{\mathrm{T}}$ was isolated from the sputum of a patient with pneumonia. Corynebacterium hansenii DSM

The GenBank/EMBL/DDBJ accession number for the $16 \mathrm{~S}$ rRNA gene sequence of strain IMMIB L-999 $\left(=\right.$ DSM $45148^{\top}=$ CCUG $\left.55795^{\top}\right)$ is AM930556 and that for Corynebacterium hansenii DSM $45109^{\top}$ is AM946639.

An extended version of the neighbour-joining phylogenetic tree is available with the online version of this paper.
$45109^{\mathrm{T}}$ was obtained from the German Culture collection (DSMZ) and used as a reference strain. The novel strain was isolated on Columbia agar (Oxoid) supplemented with $5 \%$ sheep blood after incubation at $37{ }^{\circ} \mathrm{C}$ for $48 \mathrm{~h}$ under aerobic conditions. It was characterized biochemically using the API Coryne, API 20 Strep and API ZYM systems according to the manufacturer's instructions (bioMérieux), except for the time of incubation. Lipid requirements were determined according to a standard procedure (Riegel et al., 1994). The isomeric form of diaminopimelic acid in the cell-wall peptidoglycan was determined according to the methods of Becker et al. (1964) and whole-cell sugars were determined by the method of Lechevalier (1968). Lipids were extracted using acid methanolysis and mycolic acids were detected with TLC as described by Minnikin et al. (1980). Fatty acids were analysed as described recently by Yassin et al. (2007).

Genomic DNA extraction, PCR-mediated amplification of the $16 \mathrm{~S}$ rRNA and the purification of PCR products were carried out using previously described procedures (Rainey et al., 1996). Purified PCR products were sequenced using a Taq DyeDeoxy Terminator Cycle Sequencing kit (Applied Biosystems) as described in the manufacturer's protocol. An Applied Biosystems 310 DNA Genetic Analyzer was used for the electrophoresis of the sequence reaction products. The 16S rRNA gene sequence of strain IMMIB $\mathrm{L}-999^{\mathrm{T}}$ as well as those of the recognized species of the genus Corynebacterium retrieved from the GenBank were 
added to the ARB-database (Ludwig et al., 2004) and aligned using the appropriate tool from the ARB package. The resulting alignment was corrected manually and evolutionary trees were inferred using maximum-parsimony (Fitch, 1971), neighbour-joining (Saitou \& Nei, 1987) and maximum-likelihood (Felsenstein, 1981) methods. The evolutionary distance matrix was calculated using the correction of Jukes \& Cantor (1969). The topologies of the resultant trees were evaluated by bootstrap analyses (Felsenstein, 1985) of the neighbour-joining method based on 1000 resamplings.

Cells of strain IMMIB L-999 ${ }^{\mathrm{T}}$ stained Gram-positive and on microscopic examination appeared as irregular short, non-motile, non-spore-forming rods. Colonies were cream-yellow, circular, convex, dry and approximately $0.2-2 \mathrm{~mm}$ in diameter on Columbia blood agar after $48 \mathrm{~h}$ incubation at $37{ }^{\circ} \mathrm{C}$. Colonies were non-haemolytic. The novel organism was facultatively anaerobic, catalasepositive and oxidase-negative. Using the API Coryne test V2.1, positive results were obtained for acid production from glucose and enzymic activity was detected for $\alpha$ glucosidase, pyrazinamidase and urease. The API Coryne code for strain IMMIB L-999 ${ }^{\mathrm{T}}$ was 2011104 . Using the API ZYM test, activity was detected for ester lipase C8, ester lipase C14, leucine arylamidase, naphthol-AS-BI-phosphohydrolase and $\alpha$-glucosidase. All other enzyme tests were

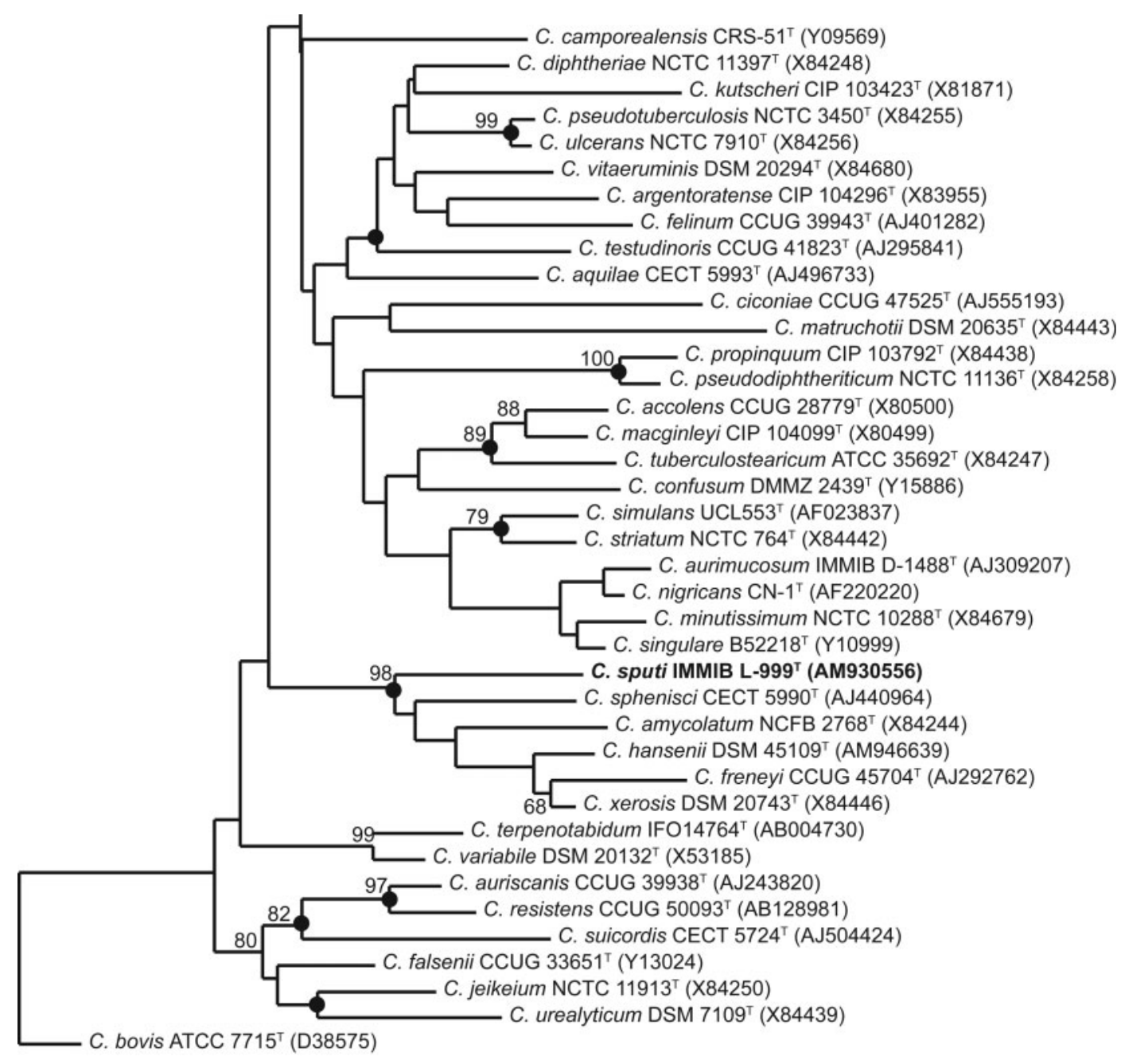

5.0

Fig. 1. Neighbour-joining phylogenetic tree showing the position of strain IMMIB L- $999^{\top}$ within the radiation of species of the genus Corynebacterium. The tree was based on a comparison of 16S rRNA gene sequences that were at least $90 \%$ complete (with regard to the sequence of Escherichia coli). The numbers at the nodes indicate the level of bootstrap support (\%) based on neighbour-joining analyses of 1000 resampled datasets; solid circles indicate that the corresponding nodes (groupings) are also recovered in maximum-likelihood and maximum-parsimony trees. Bar, 5.0\% sequence divergence. The full tree from which this figure was taken is available as Supplementary Fig. S1 in IJSEM Online. 
negative using these kits. An examination of cell-wall murein acid hydrolysates of strain IMMIB L- $999^{\mathrm{T}}$ revealed the presence of meso-diaminopimelic acid as the diagnostic diamino acid. TLC analysis of cell-wall sugars revealed the presence of galactose and arabinose, i.e. the organism possessed cell-wall chemotype IV sensu Lechevalier \& Lechevalier (1970). Lipid analysis revealed the presence of corynemycolic acids. Examination of the non-hydroxylated long-chain cellular fatty acids of the novel strain showed the presence of straight-chain saturated fatty acids $\mathrm{C}_{16: 0}$ $\left(20.96 \%\right.$ of total fatty acids), $\mathrm{C}_{17: 0}(0.61 \%), \mathrm{C}_{18: 0}$ $(17.98 \%)$, monounsaturated fatty acids $\mathrm{C}_{18: 1} \omega 9 \mathrm{c}$ $(33.68 \%), \mathrm{C}_{19: 1} \omega 9 c(2.04 \%)$ and $\mathrm{C}_{20: 1}(0.38 \%)$, diunsaturated fatty acid $\mathrm{C}_{18: 2} \omega 6,9 c(0.67 \%)$ and tuberculostearic

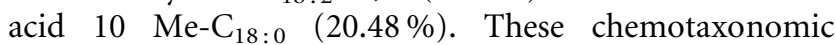
characteristics, together with the morphological and biochemical properties, were strongly indicative that the novel organism belonged to the genus Corynebacterium.

To establish the phylogenetic position of strain IMMIB $\mathrm{L}-999^{\mathrm{T}}$, the 16S rRNA gene sequence was determined in this study (1495 bp). Sequence database searches revealed that the novel bacterium was most closely related to species of the genus Corynebacterium (data not shown). Treeing analysis confirmed the placement of strain IMMIB L- $999^{\mathrm{T}}$ within the genus Corynebacterium. A tree constructed using the neighbour-joining method showing the phylogenetic position of strain IMMIB L- $999^{\mathrm{T}}$ in relation to recognized members of the genus Corynebacterium is presented in Fig. 1. Comparative 16S rRNA gene sequence analysis unequivocally demonstrated that the isolate represented a hitherto unknown species of the genus Corynebacterium. Strain IMMIB L-999 ${ }^{\mathrm{T}}$ displayed relatively high $16 \mathrm{~S}$ rRNA gene sequence similarity values (divergence values greater than $2.4 \%$ ) from other recognized species within the genus Corynebacterium. Highest sequence similarity values were shown with C. hansenii DSM $45109^{\mathrm{T}}(97.3 \%$ similarity), Corynebacterium xerosis DSM $20743^{\mathrm{T}} \quad(97.1 \%)$, Corynebacterium freneyi CCUG $45704^{\mathrm{T}} \quad(96.4 \%)$, Corynebacterium sphenisci CECT $5990^{\mathrm{T}}(96.0 \%)$ and Corynebacterium amycolatum NCFB $2768^{\mathrm{T}} \quad(95.8 \%)$. Significantly lower levels of relatedness were shown to other members of the genus Corynebacterium (data not shown). Although the novel bacterium showed close affinity with the aforementioned species, bootstrap resampling analysis showed that this association was not particularly significant.

The closest genetic relative to isolate IMMIB L- $999^{\mathrm{T}}$ was $C$. hansenii DSM $45109^{\mathrm{T}}$ displaying high $16 \mathrm{~S}$ rRNA gene sequence similarity (2.7\% divergence). Despite the relatively high sequence similarity between isolate IMMIB L- $999^{\mathrm{T}}$ and this species, isolate IMMIB L-999 ${ }^{\mathrm{T}}$ represented a distinct genomic species. It is now recognized that a $16 \mathrm{~S}$ rRNA gene sequence similarity range above $98.7-99 \%$ should be mandatory for establishing the genomic uniqueness of a novel isolate (Stackebrandt \& Ebers, 2006). In addition, it is important to note that many genomically distinct species within the genus Corynebacterium, including Corynebacterium pseudodiphtheriticum and Corynebacterium propinquum
( $>99 \%$ 16S rRNA gene sequence similarity), Corynebacterium mucifaciens and Corynebacterium afermentans $(98.5 \%$ similarity) and Corynebacterium diphtheriae, Corynebacterium ulcerans and Corynebacterium pseudotuberculosis (>98\% similarity) (Pascual et al., 1995; Ruimy et al., 1995; Funke et al., 1997b), exhibit comparable, or even higher, levels of sequence similarity. Phenotypically, isolate IMMIB L- $999^{\mathrm{T}}$ could be differentiated from C. hansenii by its ability to produce urease and its inability to produce alkaline phosphatase and acids from maltose, sucrose and ribose. Therefore, on the basis of both phenotypic and molecular genetic evidence, we are of the opinion that isolate IMMIB L- $999^{\mathrm{T}}$ merits classification as a novel species of the genus Corynebacterium, for which the name Corynebacterium sputi sp. nov. is proposed. Tests that serve to differentiate Corynebacterium sputi sp. nov. from related members of the genus Corynebacterium are shown in Table 1.

\section{Description of Corynebacterium sputi sp. nov.}

Corynebacterium sputi sp. nov. (spu'ti. L. gen. n. sputi of sputum).

Cells are Gram-positive, non-spore-forming, non-motile rods. Colonies are cream-yellow, circular, convex, dry and approximately $0.2-2 \mathrm{~mm}$ in diameter on Columbia blood agar after $48 \mathrm{~h}$ incubation at $37{ }^{\circ} \mathrm{C}$. Colonies are nonhaemolytic. Tween 80 encourages growth of the organism. Facultatively anaerobic, catalase-positive and oxidasenegative. Urea is hydrolysed, but aesculin, gelatin and hippurate are not hydrolysed. Nitrate is not reduced. Acid is produced from D-glucose, but not from L-arabinose, glycogen, inulin, D-lactose, maltose, D-mannitol, raffinose, D-ribose, D-sorbitol, starch, sucrose, trehalose, or D-xylose. Activity is detected for $\alpha$-glucosidase, lipase C8, lipase C14, leucine arylamidase, pyrazinamidase and naphthol-AS-BIphosphohydrolase. No activity is detected for acid and

Table 1. Characteristics that differentiate strain IMMIB L- $999^{\top}$ from its closest phylogenetic relatives

Strains: 1, strain IMMIB L- $999^{\mathrm{T}}$ (data from this study); 2, C. hansenii DSM $45109^{\mathrm{T}}$ (this study); 3, C. xerosis (Funke et al., 1997b; Goyache et al., 2003); 4, C. freneyi (Renaud et al., 2001); 5, C. sphenisci CCUG $46398^{\mathrm{T}}$ (Goyache et al., 2003); 6, C. amycolatum (Collins et al., 1988; Funke et al., 1997b). +, Positive; -, negative; v, variable; w, weakly positive.

\begin{tabular}{|lcccccc|}
\hline Characteristic & $\mathbf{1}$ & $\mathbf{2}$ & $\mathbf{3}$ & $\mathbf{4}$ & $\mathbf{5}$ & $\mathbf{6}$ \\
\hline Lipid requirement & + & + & - & - & - & - \\
Nitrate reduction & - & - & $\mathrm{V}$ & $\mathrm{V}$ & + & $\mathrm{V}$ \\
Production of: & & & & & & \\
Alkaline phosphatase & - & + & + & + & + & + \\
Urease & + & - & - & - & - & $\mathrm{V}$ \\
Acid production from: & & & & & & \\
Maltose & - & + & + & + & + & $\mathrm{V}$ \\
Ribose & - & + & + & $\mathrm{W}$ & - & + \\
Sucrose & - & + & + & + & - & $\mathrm{V}$ \\
\hline
\end{tabular}


alkaline phosphatases, arginine dihydrolase, chymotrypsin, cysteine arylamidase, esterase $\mathrm{C}-4, \alpha$-fucosidase, $\alpha$-galactosidase, $\beta$-galactosidase, $\beta$-glucuronidase, $\beta$-glucosidase, $N$ acetyl- $\beta$-glucosaminidase, $\alpha$-mannosidase, pyrrolidonyl arylamidase, trypsin or valine arylamidase. Acetoin production is negative. Corynemycolic acids are present. The long-chain cellular fatty acids are of the straight-chain saturated and monounsaturated types, with $\mathrm{C}_{16: 0}, \mathrm{C}_{18: 0}$ and $\mathrm{C}_{18: 1} \omega 9 \mathrm{c}$ predominating; tuberculostearic acid is present.

The type strain, IMMIB L- $999^{\mathrm{T}}\left(=\mathrm{DSM} 45148^{\mathrm{T}}=\right.$ CCUG $\left.55795^{\mathrm{T}}\right)$, was isolated from the sputum of a patient with pneumonia.

\section{Acknowledgements}

We thank Professor Dr Hans-Georg Trüper for nomenclatural advice.

\section{References}

Becker, B., Lechevalier, M. P., Gordon, R. E. \& Lechevalier, H. A. (1964). Rapid differentiation between Nocardia and Streptomyces by paper chromatography of whole cell hydrolysates. Appl Microbiol 12, 421-423.

Collins, M. D., Burton, R. A. \& Jones, D. (1988). Corynebacterium amycolatum sp. nov., a new mycolic acid-less Corynebacterium species from human skin. FEMS Microbiol Lett 49, 349-352.

Collins, M. D., Hoyles, L., Foster, G., Sjödén, B. \& Falsen, E. (2001). Corynebacterium capitovis sp. nov., from a sheep. Int J Syst Evol Microbiol 51, 857-860.

Collins, M. D., Hoyles, L., Foster, G. \& Falsen, E. (2004). Corynebacterium caspium sp. nov., from a Caspian seal (Phoca caspica). Int J Syst Evol Microbiol 54, 925-928.

Felsenstein, J. (1981). Evolutionary trees from DNA sequences: a maximum likelihood approach. J Mol Evol 17, 368-376.

Felsenstein, J. (1985). Confidence limits on phylogenies: an approach using the bootstrap. Evolution 39, 783-791.

Fernández-Garayzábal, J. F., Collins, M. D., Hutson, R. A., González, I., Fernández, E. \& Domínguez, L. (1998). Corynebacterium camporealensis sp. nov., associated with subclinical mastitis in sheep. Int J Syst Bacteriol 48, 463-468.

Fernández-Garayzábal, J. F., Vela, A. I., Egido, R., Hutson, R. A., Lanzarot, M. P., Fernández-García, M. \& Collins, M. D. (2004). Corynebacterium ciconiae sp. nov., isolated from the trachea of black storks (Ciconia nigra). Int J Syst Evol Microbiol 54, 2191-2195.

Fitch, W. M. (1971). Toward defining the course of evolution: minimum change for a specific tree topology. Syst Zool 20, 406-416.

Funke, G., Lawson, P. A. \& Collins, M. D. (1997a). Corynebacterium mucifaciens sp. nov., an unusual species from human clinical material. Int J Syst Bacteriol 47, 952-957.

Funke, G., von Graevenitz, A., Clarridge, J. E., III \& Bernard, K. A. (1997b). Clinical microbiology of coryneform bacteria. Clin Microbiol Rev 10, 125-159.

Funke, G., Osorio, C. R., Frei, R., Riegel, P. \& Collins, M. D. (1998), Corynebacterium confusum sp. nov., isolated from human clinical specimens. Int J Syst Bacteriol 48, 1291-1296.
Goyache, J., Ballesteros, C., Vela, A. I., Collins, M. D., Briones, V., Hutson, R. A., Potti, J., García-Borboroglu, P., Domínguez, L. \& Fernández-Garayzábal, J. F. (2003). Corynebacterium sphenisci sp. nov., isolated from wild penguins. Int J Syst Evol Microbiol 53, 10091012.

Jukes, T. H. \& Cantor, C. R. (1969). Evolution of protein molecules. In Mammalian Protein Metabolism, vol. 3, pp. 21-132. Edited by H. N. Munro. New York: Academic Press.

Lechevalier, M. P. (1968). Identification of aerobic actinomycetes of clinical importance. J Lab Clin Med 71, 934-944.

Lechevalier, M. P. \& Lechevalier, H. A. (1970). Chemical composition as a criterion in the classification of aerobic actinomycetes. Int J Syst Bacteriol 20, 435-443.

Ludwig, W., Strunk, O., Westram, R., Richter, L., Meier, H., Yadhukumar, Buchner, A., Lai, T., Steppi, S. \& other authors (2004). ARB: a software environment for sequence data. Nucleic Acids Res 32, 1363-1371.

Minnikin, D. E., Hutchinson, I. G., Caldicott, A. B. \& Goodfellow, M. (1980). Thin-layer chromatography of methanolysates of mycolic acid-containing bacteria. J Chromatogr 188, 221-233.

Pascual, C., Lawson, P. A., Farrow, J. A. E., Gimenez, M. N. \& Collins, M. D. (1995). Phylogenetic analysis of the genus Corynebacterium based on 16S rRNA gene sequences. Int J Syst Bacteriol 45, 724-728.

Rainey, F. A., Ward-Rainey, N., Kroppenstedt, R. M. \& Stackebrandt, E. (1996). The genus Nocardiopsis represents a phylogenetically coherent taxon and a distinct actinomycete lineage: proposal of Nocardiopsiaceae fam. nov. Int J Syst Bacteriol 46, 1088-1092.

Renaud, F. N. R., Aubel, D., Riegel, P., Meugnier, H. \& Bollet, C. (2001). Corynebacterium freneyi sp. nov., $\alpha$-glucosidase-positive strains related to Corynebacterium xerosis. Int J Syst Evol Microbiol 51, 1723-1728.

Renaud, F. N. R., Le Coustumier, A., Wilhelm, N., Aubel, D., Riegel, P., Bollet, C. \& Freney, J. (2007). Corynebacterium hansenii sp. nov., an $\alpha$ glucosidase-negative bacterium related to Corynebacterium xerosis. Int J Syst Evol Microbiol 57, 1113-1116.

Riegel, P., de Briel, D., Pre'vost, G., Jehl, F. \& Monteil, H. (1994). Genomic diversity among Corynebacterium jeikeium strains and comparison with biochemical characteristics. J Clin Microbiol 32, 1860-1865.

Ruimy, R., Riegel, P., Boiron, P., Monteil, H. \& Christen, R. (1995). Phylogeny of the genus Corynebacterium deduced from analyses of small-subunit ribosomal DNA sequences. Int J Syst Bacteriol 45, 740746.

Saitou, N. \& Nei, M. (1987). The neighbor-joining method: a new method for reconstructing phylogenetic trees. Mol Biol Evol 4, 406-425.

Stackebrandt, E. \& Ebers, J. (2006). Taxonomic parameters revisited: tarnished gold standards. Microbiol Today 33, 152-155.

Yassin, A. F., Steiner, U. \& Ludwig, W. (2002a). Corynebacterium aurimucosum sp. nov. and emended description of Corynebacterium minutissimum Collins and Jones (1983). Int J Syst Evol Microbiol 52, 1001-1005.

Yassin, A. F., Steiner, U. \& Ludwig, W. (2002b). Corynebacterium appendicis sp. nov. Int J Syst Evol Microbiol 52, 1165-1169.

Yassin, A. F., Chen, W. M., Hupfer, H., Siering, C., Kroppenstedt, R. M., Arun, A. B., Lai, W. A., Shen, F. T., Rekha, P. D. \& Young, C. C. (2007). Lysobacter defluvii sp. nov., isolated from municipal solid waste. Int J Syst Evol Microbiol 57, 1131-1136. 